Egyptian Journal of Rabbit Science, 28 (1): 115 -128(2018)

\title{
EFFECT OF L-TYROSINE ON PRODUCTIVE AND REPRODUCTIVE PERFORMANCE OF NEW ZEALANDWHITE DOES RABBITS
}

\author{
M.Loutfi ${ }^{1}$;H. A. Khalil ${ }^{2}$ I.M.M. Assaf ${ }^{1}$ and M. A. Ayoub ${ }^{2}$ \\ 1- Department of Poultry Nutrition, Animal Production Research Institute, \\ Agricultural Research Centre, Dokki, Giza, Egypt. \\ 2-Department of Animal Production, Faculty of Agriculture, Suez Canal \\ University, Ismailia, Egypt.
}

This study investigated the effect of L-Tyrosine according to the age at administration on some productive and reproductive performance of female New Zealand White (NZW) rabbits. Sixty five young does were distributed randomly into five equal groups in a completely random design included four levels of L-tyrosine according to the age of does at administration. The first group was served as a control, while the second (T1) was given a single dose of L-tyrosine $(100 \mathrm{mg} / \mathrm{kg} \mathrm{BW})$ at the second month of age, the third group (T2) was given two doses at 2 and at 4 months of age, the fourth group (T3) was given three doses at 2, 4 and at 6 months of age and the fifth group (T4) was given four doses at 2, 4, 6, and at 8 months of age.

The results showed the effect of $L$-tyrosine treatments on sexual receptivity and the conception rates was significant $(P \leq 0.05)$ and $(P$ $\leq 0.01)$ respectively. The highest receptivity rate was $92.86 \%$ in $T 1$ group. The conception rate increased inTl group was 93.39\%. Also L-tyrosine treatments affected significantly $(P \leq 0.05)$ on kindling intervals (days) and economic efficiency. The shortest kindling interval was in T1 group (41.75 days).T1 group was the best in economic efficiency. Also L-tyrosine affected significantly $(P \leq 0.05)$ on average total litter size and their weights at birth and at weaning where T1 gave the highest litter size.

In conclusion, the single dose of L-tyrosine at two months of age in NZW rabbits enhanced the receptivity rate, conception rate, total litter size and their weights at birth and at weaning.

Key words: Rabbits, L-tyrosine, Reproductive, Litter size, Mortality.

Several studies showed a close correlation between the level of some amino acids in the blood and reproductive performance of mammals in 
various stages of the production cycle in animals (Gabr, 2009).El-Amrawi (2008) found that treatment of some amino acids, especially L-tyrosine at a specific stage of age led to significant improvement in reproductive and productive performance in farm animals. These organic substances are believed to have positive effect on animal production and reproductive performance through enhancing the release of sex hormones (Gabr, 2009). L-tyrosine acid is necessary for the synthesis of catecholamines (adrenaline, noradrenaline and dopamine), thyroxin hormone from thyroid gland, in addition, to its important role in the citric acid cycle and building of melanin (Harper et al., 1980). It has been found that the effect of pituitary gonadotropins (FSH \& LH) on gonads is more hastened when thyroxin level is at the peak (Hall et al., 1992). L-tyrosine serves as a precursor for the synthesis of dopamine, norepinephrine, and epinephrine which are a specific brain neurotransmitter implicated in the control of GnRH and LH (Ramirez et al., 1984).Abo-Elroos, (1992) reported that L-tyrosine improved the reproductive efficiency of the rabbit, through enhancing the release of sex hormones.Also L-Tyrosine appeared to increase live body weights, conception rate, milk yield, litter size, litter weights and decrease mortality rate (Kandil et al., 2001., Omara et al., 2005., Noseir et al., 2007 and Gabr, 2009). L-Tyrosine supplementation increased the economic efficiency in rabbits (Omara et al., 2005) and in ewes (Ibrahim, 2010).

Therefore, the aim of the present work was to study the effect of Ltyrosine administration on productive and reproductive performance of the female in New Zealand White (NZW) rabbits and growth performance of the offspring as well.

\section{MATERIALS AND METHODS}

The present study was carried out at a private rabbit farm in Husseiniya, Sharkia governorate, Egypt, from January, 2016 to February, 2017. Sixty five young NZW does were randomly distributed into five equal groups in a completely random design included four intervals doses ofL-tyrosine according to the age at administration. The first group was served as a control (no treatment), while the second group (T1) was given a single dose of L-tyrosine $(100 \mathrm{mg} / \mathrm{kg} \mathrm{BW})$ at the second month of age, the third group (T2) was given two doses at 2 and 4 months of age, the fourth group (T3) was given three doses at 2, 4and at 6 months of age and the fifth group (T4) was given four doses at 2, 4, 6, and 8 months of age. 
L-tyrosine (99\% purity) was purchased from Alpha Chemika Company, Mumbai- India. L-tyrosine powder was dissolved in distilled water. A $5 \mathrm{ml}$ syringe was used for application of the oral dose to each rabbit in assigned group.

At the beginning of the experiment, age of animals averaged 2 months and their average weight was similar(1544.22 $\pm 10.78 \mathrm{~g})$. Rabbits were continuously kept under the same managerial and environmental conditions during the whole experimental period. Rabbits were healthy and free of any external parasites or skin diseases. All rabbits were individually housed in galvanized wired cages, where feed and water were provided ad libitum. Rabbits were fed on basal pellet ration contained yellow corn, soybean meal, clover hay, minerals and vitamins premix. The chemical composition of the commercial pelleted dietwas as the following: crude protein $17.03 \%$, ether extract $2.40 \%$,crude fiber $12.65 \%$ and digestible energy 2675.00 $\mathrm{Kcal} / \mathrm{Kg}$.

Data of the experiments were collected and calculated as follows: body weight was determined for each doe at two and at five months of age, at every mating and at every parturition up to nine months. Sexual receptivity percent was calculated as a percentage of the number of mated females from all females provided to mating. The conception rate was calculated for each treatment by the following equation: conception rate $=$ (number of pregnant does/ number of mated does) X 100. Kindling intervals (days) were recorded from two consecutive kindling during the experimental period. Number of parities for each doe was recorded from number of parties during the experimental period. Daily mortality was recorded and mortality rate was calculated for the whole experimental period. The economic efficiency (EE) was calculated as follows: net revenue $=$ total revenue (price of doe and average litter weight at weaning) total feed costs (including L-tyrosine cost) for doe from May 2016 to January 2017. The litter size (total alive / dead) and their weights were recorded at different periods (birth and weaning at 30 days of age).Daily mortality was recorded and mortality rate was calculated at different periods (birth and weaning at 30 days of age) by the following equations:

Mortality rate at birth $=($ Dead kits at birth/ Total litter size at birth $) \times 100$.

Mortality rate at weaning $=[($ Total litter size at birth - Alive kits number at weaning) / Total litter size at birth] x 100.

Data were statistically analyzed using analysis of variance procedure described by IBM SPSS (2011) and The mathematical model was:

$$
Y_{i j}=\mu+A_{i}+e_{i j}
$$


Where $Y_{i j}=$ An observation, $\mu=$ The overall mean, $A_{i}=$ Effect of $L$ tyrosine treatments $(i=1$ to 5$)$ and $\mathrm{e}_{\mathrm{ij}}=$ Random error.

Significant differences among treatments were tested by Duncan's Multiple Range Test (Duncan, 1955).

\section{RESULTS AND DISCUSSION}

\section{Live body weight (LBW):}

As shown in Table (1) at the start of the experiment, LBW of does at two months of age were equal, and no significant differences among the weights were found at 5 months of age. Furthermore, no significant differences were detected at mating and at every parturition. These results were in agreement with Afet (2014) who reported that the supplementation of L-tyrosine had no effect on LBW at puberty, service and during conception in Friesian heifers. As well as in Ossimi ewes, Ibrahim (2010) did not find any significant differences as result of L-Tyrosine treatments in LBW at mating, during pregnancy and post every lambing compared to the control group. On the other hand, these results are in disagreement with the obtained results by Omara et al. (2005); Noseir et al. (2007) and Gabr (2009) who reported that addition of L-Tyrosine led to increase in LBW in growing NZW rabbits. These differences may be attributed to marked breed differences and/or environment and management variation (Afet, 2014).

\section{Sexual receptivity rate:}

The effect of L-tyrosine treatments on sexual receptivity was significantly $(\mathrm{P} \leq 0.05)$ varied between treated groups and control group (Table2). The highest receptivity was $92.86 \%$ in T1 group and 65.17, 62.54, 62.82 and $78.71 \%$ in the control, T2, T3 and T4 groups respectively. Increasing in receptivity rate was associated with the increase in estradiol $\left(E_{2)}\right.$ hormone level as reported by Caillol et al.,(1983) who found a direct relation between plasma $E_{2}$ mean levels and high or low sexual receptivity during the post-partum period. Ubilla and Rebollar (1994) supported this result where the reproductive activity was stimulated by estrogen. 
Table (1). Live body weight of does (g) at different ages and status of does as affected by administration of L-Tyrosine during the experimental period (Mean \pm S.E)

\begin{tabular}{ccccc}
\hline Treatment & $\begin{array}{c}\text { Two } \\
\text { months }\end{array}$ & $\begin{array}{c}\text { Five } \\
\text { months }\end{array}$ & $\begin{array}{c}\text { Every } \\
\text { mating }\end{array}$ & $\begin{array}{c}\text { Every } \\
\text { parturition }\end{array}$ \\
\hline \multirow{2}{*}{ Control (0 dose) } & 1553.00 & 3075.77 & 3043.01 & 2961.39 \\
& \pm 29.87 & \pm 57.14 & \pm 48.99 & \pm 44.72 \\
T1(1 dose) & 1544.15 & 3078.08 & 3123.88 & 2986.93 \\
& \pm 30.09 & \pm 90.53 & \pm 70.61 & \pm 82.33 \\
T2 (2 doses) & 1540.69 & 3010.69 & 2979.57 & 2866.45 \\
& \pm 20.50 & \pm 98.33 & \pm 33.18 & \pm 41.74 \\
T3 (3 doses) & 1533.77 & 3086.15 & 3098.07 & 3011.11 \\
& \pm 21.29 & \pm 69.78 & \pm 75.57 & \pm 71.97 \\
T4 (4 doses) & 1549.46 & 3111.50 & 3137.62 & 3024.54 \\
\hline Significance & \pm 20.23 & \pm 67.27 & \pm 57.36 & \pm 68.25 \\
\hline NS = Not significant & NS & NS & NS & NS
\end{tabular}

Table (2). Effect of L-tyrosine treatments on NZWdoes sexual receptivity rate $\%$, conception rate $\%$, kindling interval, number of parities, doe mortality rate(Mean \pm S.E)

\begin{tabular}{|c|c|c|c|c|c|}
\hline Treatments & Receptivity\% & $\begin{array}{c}\text { Conception } \\
\%\end{array}$ & $\begin{array}{c}\text { Kindling } \\
\text { interval } \\
\text { (days) }\end{array}$ & $\begin{array}{c}\text { No of } \\
\text { parities }\end{array}$ & $\begin{array}{c}\text { Mortality } \\
(\%)\end{array}$ \\
\hline Control & $65.17 \pm 9.86^{\mathrm{b}}$ & $\begin{array}{l}76.16 \pm \\
4.90^{\mathrm{bc}}\end{array}$ & $\begin{array}{l}45.04 \pm \\
1.49^{\mathrm{ab}}\end{array}$ & $\begin{array}{l}5.09 \pm \\
0.21^{\mathrm{ab}}\end{array}$ & $\begin{array}{c}07.69 \pm \\
07.69^{\mathrm{b}}\end{array}$ \\
\hline T1 & $92.86 \pm 3.72^{\mathrm{a}}$ & $\begin{array}{c}93.39 \pm \\
3.54^{\mathrm{a}}\end{array}$ & $\begin{array}{c}41.75 \pm \\
1.29^{\mathrm{b}}\end{array}$ & $\begin{array}{c}5.64 \pm \\
0.15^{\mathrm{a}}\end{array}$ & $\begin{array}{l}07.69 \pm \\
07.69^{\mathrm{b}}\end{array}$ \\
\hline $\mathbf{T} 2$ & $62.54 \pm 9.85^{\mathrm{b}}$ & $\begin{array}{l}81.91 \pm \\
4.29^{\mathrm{ab}}\end{array}$ & $\begin{array}{c}45.51 \pm \\
2.36^{\mathrm{ab}}\end{array}$ & $\begin{array}{l}5.20 \pm \\
0.20^{\mathrm{ab}}\end{array}$ & $\begin{array}{l}15.39 \pm \\
10.42^{\mathrm{ab}}\end{array}$ \\
\hline $\mathbf{T 3}$ & $62.82 \pm 8.44^{\mathrm{b}}$ & $\begin{array}{l}69.15 \pm \\
5.24^{\mathrm{bc}}\end{array}$ & $\begin{array}{c}45.25 \pm \\
1.67^{\mathrm{ab}}\end{array}$ & $\begin{array}{l}4.90 \pm \\
0.18^{\mathrm{b}}\end{array}$ & $\begin{array}{c}07.69 \pm \\
07.69^{\mathrm{b}}\end{array}$ \\
\hline T4 & $78.71 \pm 8.09^{\mathrm{ab}}$ & $\begin{array}{l}65.49 \pm \\
7.95^{\mathrm{c}}\end{array}$ & $\begin{array}{c}49.46 \pm \\
3.59^{\mathrm{a}}\end{array}$ & $\begin{array}{l}5.00 \pm \\
0.27^{\mathrm{b}}\end{array}$ & $\begin{array}{c}23.08 \pm \\
12.16^{\mathrm{a}}\end{array}$ \\
\hline Significance & $*$ & $* *$ & $*$ & $*$ & $*$ \\
\hline
\end{tabular}




\section{Conception rate:}

The effect of L-tyrosine treatments on conception rate \%was significant $(\mathrm{p} \leq 0.01)$ as shown in Table (2). L-tyrosine treatment increased the conception rate in T1 group to be $93.39 \%$ compared the other groups $\mathrm{T} 2$, T3, T4 and control group. In the meantime L-tyrosine treatment decreased the conception rate in groups T3 and T4 compared to control group but without significant. The present results agreed with Kandil et al. (2001) who reported that L-tyrosine administration in rabbits raised pregnancy rate and increased litter size. This increment in conception rate was due to L-tyrosine treated rabbits of two month age where numerous Graafian follicles with thickened zona pellucida were noticed, stroma appeared highly vascular; there was a marked increase in the number and size of the interstitial gland cells (Abo-Elroos, 1992).

\section{Kindling intervals:}

L-tyrosine treatments had a significant effect $(\mathrm{P} \leq 0.05)$ on Kindling intervals (days) as shown in Table (2). The shorter kindling interval(41.75 days) was found in T1 group and the longest one was in T4 group (49.46 days). However, there were no significant differences among treated group T1, T2, T3 and control groups which being 41.75, 45.51, 45.25 and 45.04 days respectively. These results may bedue to correlation between conception rate and the kindling intervals and the effect of L-tyrosine treatments on conception rate as shown in Table (2).The least rate was in T4 whereas the highest was seen in T4. These results were in agreementwith (Rettmer et al., 1993) who reported that L-tyrosine treatmentresulted to reduce the post-weaning interval to conception in rats and gilts by stimulating catecholamine synthesis.

\section{Number of parities:}

Number of parities was significantly affected by the L-tyrosine treatment of L-tyrosine $(\mathrm{P} \leq 0.05)$ as presented in Table $(2)$. The treated groupT1 was the best (5.64) whereas the least was T3 (4.90) then T4 (5.00).It may be due to the effect of L-tyrosine treatments on conception rate, however, the least effect was in $\mathrm{T} 4$ where repeated L-tyrosine doses decreased the number of parities in T4. The use of L-tyrosine oral dose increases ovulation rate and thus incidence of multiple births. These findings may be due to the administration of L-tyrosine prior to insemination increased yield of fertilized ova in the doe and initiated a new wave of follicular development and improved the number of ovulation (Cognie, 1990). After mating, the results showed a bad effect when we used 
L-tyrosine. Gabr (2012) showed that L-tyrosine inhibited follicular growth in the ovary which led to a decreasing in the average number of estrus cases and ovulatory cycles per cow during the ovulatory cycles. Also Wetzel(1985), Hammerl (1986) and Munsterer (1987) found low number of estrus per cow was associated with the exogenous L-tyrosine treatment.

\section{Does mortality rates:}

L-tyrosine treatments insignificantly increased does mortality rate with repeated treatment during experiment period compared to control group. The treated group of $\mathrm{T} 4$ which was treated four times with L-tyrosine showed the highest mortality rate $(23.08 \%)$ during the whole experimental as shown in Table (2). These results are similar with Abu El-Ella et al. (2011) who found that mortality rate of L-Tyrosine level ( $150 \mathrm{mg} / \mathrm{kg}$ body weight) was higher than that of L-Tyrosine level (100 mg $/ \mathrm{kg}$ body weight) in goats does. These results may be due to decarboxylate L-tyrosine to tyramine, a biogenic amine in intestine. The potential microbial synthesis of tyramine in the foregut of the ruminants and hindgut of all animals showing a significant microbial load in the gastrointestinal tract, and should not be dismissed (European safety food authority, 2013). Tyramine may be produced by a variety of Gram-positive bacteria, including lactobacilli and enterococci, and by Gram-negative bacteria (Nugon-Baudon et al., 1985a, b; Dierick et al., 1986; Shalaby, 1996; Marcobal et al., 2012). Inadequate degradation (detoxification) of tyramine may cause adverse health effects on individuals (Nugon-Baudon et al., 1985a, b; Shalaby, 1996; Pietzak et al., 2002).

\section{Litter size:}

The litter size was recorded at birth as a total number to every doe during the whole experimental period. The presented data in Table (3) shows that the effect of L-tyrosine treatments on average total litter size at birth and at weaning. L-Tyrosine treatments had a significantly $(\mathrm{P} \leq 0.05)$ effect on average of total litter size at birth and weaning. The results showed that the treated does with L-Tyrosine at two months of age in T1 group gave the best litter size and the treated does with four doses of L-Tyrosine at 2, 4, 6 and at 8 months of age in T4 group gave the least litter size. Meanwhile there were no significantly differences among the other groups of T2, T3 and control groups.

The obtained results due to single dose of L-Tyrosine at two months of age are in agreement with Omara et al. (2005) who reported that LTyrosine administration in NZW rabbits raised pregnancy rate and increased litter size. In this context, Omara et al. (2005) guessed that L-Tyrosine 
Table (3). Effect of L-Tyrosine treatments on average total litter size and total litter weight at birth and weaning(Mean \pm S.E)

\begin{tabular}{ccccc}
\hline \multirow{2}{*}{ Treatments } & \multicolumn{2}{c}{ Total litter size } & \multicolumn{2}{c}{ Total litter weight } \\
\cline { 2 - 5 } & At birth & $\begin{array}{c}\text { At } \\
\text { weaning }\end{array}$ & At birth & At weaning \\
\hline \multirow{2}{*}{ Control } & 35.00 & $29.36 \pm$ & $1592.45 \pm$ & $14119.00 \pm$ \\
& $\pm 2.39^{\mathrm{b}}$ & $2.07^{\mathrm{b}}$ & $68.27^{\mathrm{b}}$ & $633.98^{\mathrm{b}}$ \\
$\mathrm{T} 1$ & 39.56 & $33.88^{\mathrm{a}}$ & $1869.33^{\mathrm{a}} \pm$ & $16660.33^{\mathrm{a}}$ \\
& $\pm 1.85^{\mathrm{a}}$ & $1.48^{\mathrm{a}}$ & $61.11^{\mathrm{a}}$ & $371.56^{\mathrm{a}}$ \\
$\mathrm{T} 2$ & 34.70 & $28.70^{\mathrm{b}}$ & $1609.70 \pm$ & $13872.70 \pm$ \\
& $\pm 1.32^{\mathrm{b}}$ & $1.51^{\mathrm{b}}$ & $69.56^{\mathrm{b}}$ & $598.9^{\mathrm{b}}$ \\
$\mathrm{T} 3$ & 35.50 & $30.40^{\mathrm{a}} \mathrm{b}$ & $1606.10 \pm$ & $14765.40 \pm$ \\
& $\pm 2.00^{\mathrm{b}}$ & $1.50^{\mathrm{b}}$ & $81.84^{\mathrm{b}}$ & $636.74^{\mathrm{b}}$ \\
$\mathrm{T}$ T4 & 29.00 & $24.71 \pm$ & $1361.25 \pm$ & $13815.25 \pm$ \\
& $\pm 2.51^{\mathrm{c}}$ & $2.15^{\mathrm{c}}$ & $59.86^{\mathrm{c}}$ & $865.21^{\mathrm{b}}$ \\
\hline Significance & $*$ & $*$ & $* * *$ & $*$ \\
\hline
\end{tabular}

${ }_{a, b, c}$ Means with different superscripts in the same column are significantly different with respect to their P-values.

NS $=$ Not significant,$\quad *$ Significant at $\mathrm{P}<0.05, * *$ Significant at $\mathrm{P}<0.01$.

increased number of mature ovarian follicle which reach maturity and became ready for ovulation at mating. The use of L-Tyrosine oral dose increases ovulation rate and thus incidence of multiple births. It may be due to treatments of L-Tyrosine prior to insemination which increased yield of fertilized ova in the doe and initiated a new wave of follicular development and improved the number of ovulation (Cognie, 1990).

On the other hand, (Gindele and Koppen, 1989) reported that the litter size of sows received L-Tyrosine was similar to that of controls. Also Able (1988) reported that no beneficial effect of L-Tyrosine supplementation on litter size and did not observe larger litter sizes in treated gilts.

\section{Litter weight:}

Litter weight was recorded at birth and weaning as presented in Table (3). Results show significant differences $(\mathrm{P} \leq 0.001)$ among the treated groups and control at birth. Treated group of T1 gave the highest weight (1869.33 g) compared to all other groups while the treated group of T4 gave the lighter weight $(1361.25 \mathrm{~g})$ compared to all other groups. Also, there are no significant differences among treated groups T2, T3 and control group. In the 
meantime, there are significant differences $(\mathrm{P} \leq 0.05)$ among the treated groups and other studied groups at weaning. Treated groupT1gave the highest weight $(16,660.33 \mathrm{~g})$ compared to all other groups while the treated does in groups T2, T4 gave the lighter weight compared to all other groups. However no significant differences among treated groups T2, T3, T4 and control group were detected.

These findings were in agreement with Kandil et al. (2001) who found that L-Tyrosine increased litter weights at birth and at weaning in treated rabbit does compared to control group. But this results were in disagreement with Omara et al. (2005) who revealed that, litter weight at birth was not significant different between control and treated does in NZW rabbits. Also Ibrahim (2010) and Abu El-Ella et al. (2011) found that the birth weights were not significantly different between the control group and treated ewes with L-Tyrosine.

\section{Total litter mortality rate:}

Mortality was recorded and total mortality rate was calculated at different periods (at birth and weaning at 30 days of age) as shown in Table (4). The effect of L-tyrosine treatments on mortality rate at birth and weaning was not significant among the treated groups and control group. Although the litter size in T1 was more than other groups but the finally mortality rate was similar and no significantly differences among all groups. These results are similar with Omara et al. (2005) who found an increase in total litter mortality in females treated with L-Tyrosine in NZW rabbits. But these findings were in disagreement with As well Ibrahim (2010) in sheep and Kandil et al. (2001) in NZW who reported that L-Tyrosine administration decreased litter mortality rate in treated does compared to control does in NZW rabbits.

\section{Economic efficiency :}

The effect of L-tyrosine treatments on economic efficiency was significant $(\mathrm{P} \leq 0.05)$ during experiment period. Group $\mathrm{T} 1$ was the highest in economic efficiency $(39.06 \%)$ at the experiment end while there were no significant differences between $\mathrm{T} 2, \mathrm{~T} 3, \mathrm{~T} 4$ and control groups which being27.12, 31.35, 26.82, 29.25\%, respectively as shown in Table (4). The previous results agreed with Abu EI-Hamd et al., (2012) who found that the L-tyrosine treatment improved the feeding values and economic efficiency of calves.Also in sheep, Ibrahim (2010) and Yassin et al. (2011) reported that treated ewes with L-Tyrosine treatment was economically better compared to the control. 
Table (4). Effect of L-tyrosine treatments on total mortality rate (at birth and at weaning) and economic efficiency(Mean \pm S.E)

\begin{tabular}{|c|c|c|c|}
\hline Treatments & $\begin{array}{c}\text { Mortality rate } \\
\text { at birth }(\%)\end{array}$ & $\begin{array}{c}\text { Mortality rate } \\
\text { at weaning }(\%)\end{array}$ & $\begin{array}{c}\text { Economic efficiency } \\
(\%)\end{array}$ \\
\hline Control & $5.63 \pm 2.07$ & $15.94 \pm 2.78$ & $29.25 \pm 0.03^{b}$ \\
\hline $\mathrm{T} 1$ & $6.39 \pm 2.26$ & $15.68 \pm 2.25$ & $39.06 \pm 0.01^{\mathrm{a}}$ \\
\hline $\mathrm{T} 2$ & $8.83 \pm 2.34$ & $15.51 \pm 2.50$ & $27.12 \pm 0.03^{\mathrm{b}}$ \\
\hline $\mathrm{T} 3$ & $4.16 \pm 1.70$ & $13.83 \pm 1.98$ & $31.35 \pm 0.03^{b}$ \\
\hline $\mathrm{T} 4$ & $5.90 \pm 2.66$ & $11.11 \pm 3.21$ & $26.82 \pm 0.04^{\mathrm{b}}$ \\
\hline Significance & NS & NS & $*$ \\
\hline
\end{tabular}

\section{CONCLUSION}

The effect of using a single dose ofL-tyrosine (100 mg/kg BW) at two months of age had significant effect and enhanced the receptivity rate, conception rate, total litter size andtheir weights at birth and at weaning of NZW does.

\section{REFERENCES}

Able, F. (1988). Beeinflussung der Fruchtbarkeit bei Sauen wahrend der Sommermonate durch perorale Gabe von L-tyrosin. Ph.D. Dissertation. Ludwig-Maximilians-University, $\mathrm{M}$ unich, FRG.

Abo-Elroos, M.A. (1992). Effect of L-tyrosine on the pituitary and gonads of rabbits in relation to 60 sexual maturity. M. V. Sc. Thesis, Zagazig University, Faculty of Vet. Med. Moshtoher, Banha.

Abu El-Ella, A. A., El-Gohary, E. S., Abdel-Khalek, T. M. M. and Abdel-Samee, A. M. (2011). Productive and reproductive performance of goats as affected by L-Tyrosine supplement: Sexual activity and reproductive performance. Egyptian Journal of Sheep \& Goat Sciences, Vol. 6 (2), 37 - 46.

Abu El-Hamd, M. A., Sayah, M.S., Shamiah, Sh. M. and Gabr, Sh. A. (2012). Effect of 1-tyrosine on growth performance and some blood constituents of suckling Friesian calves during winter and summer seasons. Egyptian J. Anim. Prod., 49 Suppl. Issue: 57-63. 
Afet, M. G. (2014). Effect of L-tyrosine supplementation on productive and reproductive performance in Friesian heifers. M. Sc. Thesis, Fac. Agric. Kafrelsheikh University. Egypt.

Caillol, M., Dauphin-Villemant, C. and Martinet, L. (1983). Oestrus behavior and circulation progesterone and estrogen levels during pseudo pregnancy in the domestic rabbit. J. Prod. Fertil., 69:179.

Cognie, Y. (1990). Current technology for synchronization and artificial insemination of sheep. World Sheep and Wool Congress, 16:207216.

Dierick, N., Vervaeke, J., Decuypere, J. and Henderickx, H. (1986). Influence of the gut flora and of some growth promoting feed additives on nitrogen metabolism in pigs. Livestock Production Science, 14, 161-193.

Duncan, D. B. (1955). Multiple range and multiple F-test. Biometrics, 11: $1-42$.

El-Amrawi, G.A. (2008). Effect of Theriogon in concentration of testosterone in buffalo-bulls. $16^{\text {th }}$ International Congress on Animal Reproduction (ICAR), 12-16 Juli Budapest. Hungura.

European Food Safety Authority. (2013). Scientific opinion on the safety and efficacy of L-tyrosine for all animal species.1 EFSA Journal; 11(7):3310.

Gabr, Sh. A. (2009). The relay of sexual puberty in rabbit male by L $-\mathrm{L}$ tyrosine or carnitine treatment. J. Agric. Res., Kafrelsheikh Univ., 35: 56-68

Gabr, Sh. A. (2012). Reproductive performance and milk yield of Friesian dairy cows affected by L-tyrosine treatment during early postpartum period. Life Sci J 2012; 9(4): 4486-4489. (ISSN:1097 8135).

Gindele, H. R., and Koppen, W. D. (1989). Kann durch orale Verabreichung von L-tyrosin die Reproduktionsleistung bei Sauen gesteigert werden? Tieraerztl. Umsch. 44:528.

Hall, J.B., K.K. Schillo, S.M. Hileman, and Boling, J.A. (1992). Does Ltyrosine act as a nutritional signal mediating the effects of increased feed intake on luteinizing hormone patterns in growthrestricted lambs? Biol. Reprod., 46: 573-579.

Hammerl, J. (1986). Der Einfluß der Aminosaure L-Tyrosin, als ein Katecholamin-Vorlaufer, auf die Reproduktion bei $\mathrm{Ku}$ “" hen. In: Proc. 14th World Cong. on Diseases of Cattle. Vol 2. p 911. Dublin, U.K. 
Harper, H.A., Rodwell, V. W., and Mayes, P.H. (1980). Review of Physical Chemistry, 17th Edition, Longer Medical Publication, Los Altos, 34, 511.

IBM SPSS Statistics. (2011). Statistical package for the social sciences, Release: V.20, SPSS INC, Chicago, USA.

Ibrahim, M. Y. M. (2010). Some studies on improving productive and reproductive performance of local sheep. Ph.D. Fac. Agric Minia Univ., Egypt.

Kandil, O. M., R.I. El-Sheshtawy and Sebra, H.A. (2001). Effect of Ltyrosine and bovi C3 supplementation, sire breed and superovulation on some reproductive performance of Egyptian rabbit. J. Egypt Vet. Med. Assoc., 61 (6): 207-216.

Marcobal, A., De Las Rivas, B., Landete, J. M., Tabera, L. and Munoz, R. (2012). Tyramine and phenylethylamine biosynthesis by food bacteria. Critical Reviews in Food Science and Nutrition, $52,448-467$.

Munsterer, P. (1987). Zur Anwendung der aminosure Ltyrosin in der sterilitats behandlung des Milchrindes. Diss. Med Vet., Munchen.

Noseir, W.M.B., Abboud, M.Y.A., Amrawi, G.A., and Lotfy, T.M.E.(2007). Effect of Administration of L-tyrosine and LCarnitine on Onset of Puberty in Rabbits. Veterinary Medical Journal, Giza, Vol. 55, No. 4: 1111-1122.

Nugon-Baudon, L., Szylit, O., Chaigneau, M., Dierick, N. and Raibaud, P. (1985 a). Production d'amines in vitro et in vivo par une souche de Lactobacillus isolée d'un jabot du coq. Annales de l'Institut Pasteur/Microbiologie, 136B, 63-73.

Nugon-Baudon, L., Szylit, O., Chaigneau, M., Dierick, N. and Raibaud, P. (1985 b). Production of amines in monoxenic chicken inoculated with a Lactobacillus strain isolated from holoxenic (conventional) cock crop. In: Germfree Research: microflora and its application in biomedical sciences. Ed Wostmann B. Alan Riss Inc., New York, USA, 119-122.

Omara, M. E., Mahmoud, S., A. and Saad, M. F. (2005). Effect of LTyrosine on productive and reproductive performance of female New Zealand rabbits. Vet. Med. J. ,Giza, Vol. 53, No.2. 381-394.

Pietzak T, Schad A, Zentek J and Mosenthin, R. (2002). Biogene Amine in die Tierernährung: Entstehung, Stoffwechsel und physiologische Aspekte. Ubers. Tierernährung, 31, 37-64. 
Ramirez, V.D., Feder, H.H., and Sawyer, C.H. (1984). The role of brain catecholamines in the regulation of LH secretion: A critical inquiry. In: L. Martini and W. F. Ganong (Ed.) Frontiers in Neuroendocrinology (Vol. 8). p 27. Raven Press,New York, USA.

Rettmer, I., Goodband, R. D, Stevenson, J.S, Davis, D. L, Tokach, M. D, Rozeboom, D. W, Pettigrew, J. E, Johnston, L. J, Rust, J. W. and Chester-Jones, H.(1993). Failure of dietary amino acid supplementation at weaning to influence reproductive traits of sows. Journal of Animal Science, 71, 2511-2515.

Shalaby, A. ( 1996). Significance of biogenic amines to food safety and human health. Food Research International, 29, 675-690.

Ubilla, E. and Rebollar, P.G. (1994). A study of sexual receptivity and plasma estradiol-17b levels through the lactation period in rabbit. 1st international Conference held in Cairo, Egypt, 6-8 September 1994. Vol. 8: 377.

Wetzel, G. (1985). Der Einfluß der Aminosaure L-tyrosine auf das Fruchtbarkeitsgeschehen beim Rind. Vet. Dissertation. Univ. of Munich, Germany.

Yassin, M., El-Barody, M. A., Gabr, M. G. K., Safaa, N. A., Elmoty, A. K. I. A., El-Hakeam, A. A. A. (2011). Post-lambing productive and reproductive performance of Ossimi ewes as affected by Theriogon oral administration during three sequence breeding seasons. Egyptian Journal of Nutrition and Feeds. 14(3):359-365.






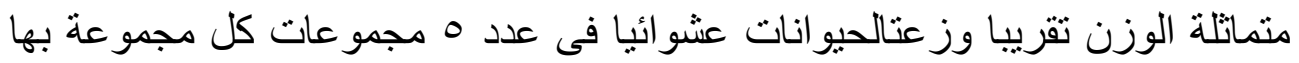

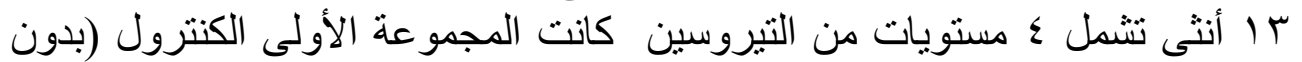

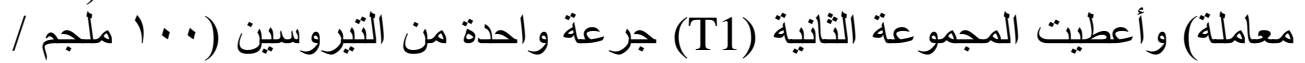

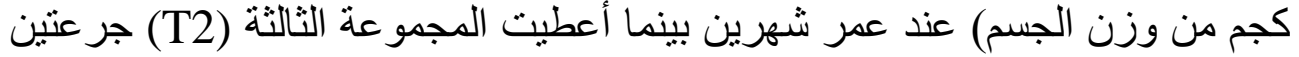

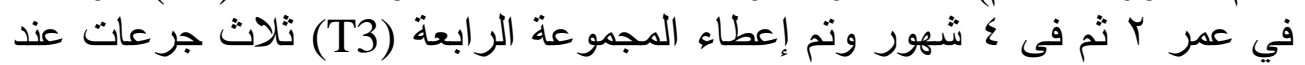

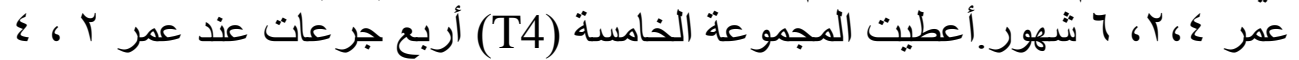
، 1 ، 1 شهور . وأظهرت المعاملات النتائج النالية:

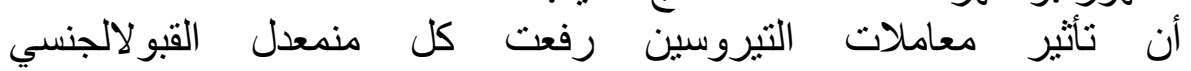

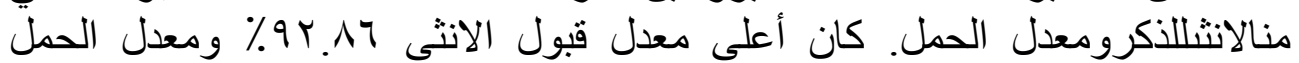

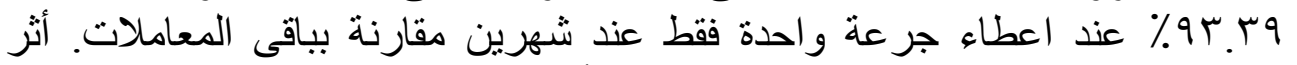



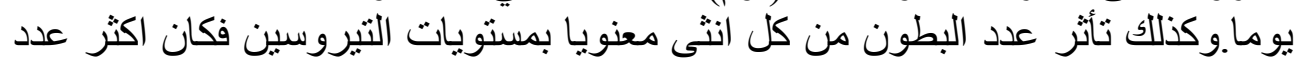

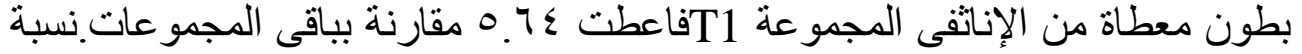

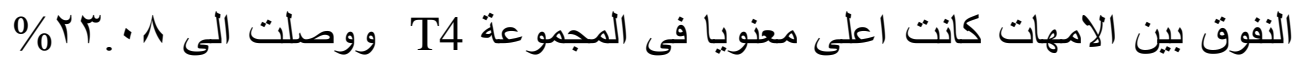

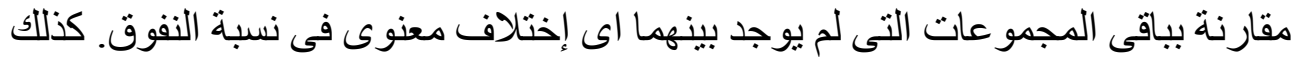

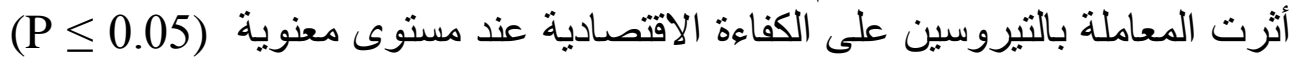

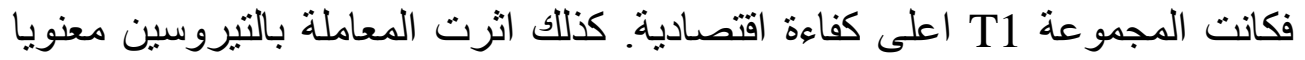

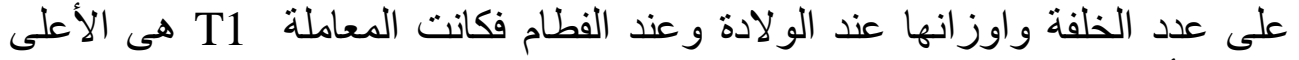

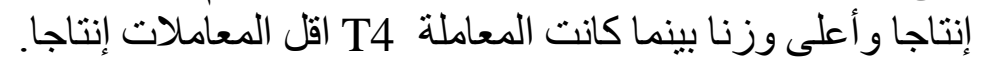

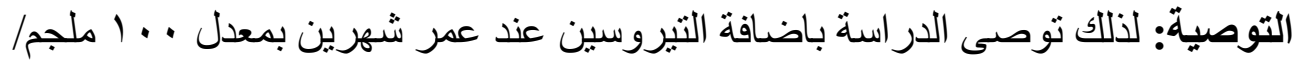

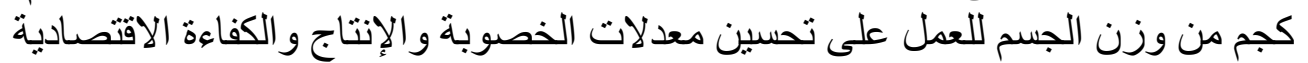

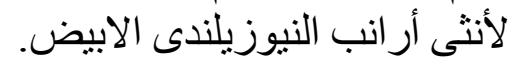
الكلمات الإفتتاحية: التيروسينـ ار انبـ النيوزيلندى الابيضـ التناسل_عدد الخلفة_النفوق 